\title{
Pesimismo, realismo y por los caminos (ambiguos) de Asia
}

\author{
Pessimism, realism and the (ambiguous) paths of Asia
}

Pablo Amadeo, (2020). Sopa de Wuhan. Argentina: Editorial Aislamiento Social Preventivo y Obligatorio (ASPO). 188 pp.

\author{
Luis Alberto Carmona Sánchez \\ Universidad Nacional de Colombia sede Manizales, Profesor. \\ Magíster en Filosofía moral y política, Sociólogo, ambos títulos otorgados por la Universidad de Caldas. Integrante \\ Grupo de investigación ETHOS, Universidad Nacional de Colombia sede Manizales. \\ Email: luacarmonasa@unal.edu.co
}

Doi:https://doi.org/10.22267/rceilat.214849.102

\section{Introducción}

En la actualidad, nada que no tenga relación con la Covid-19, al parecer, no reviste importancia destacada ante el mundo. El mundo se ha tornado monosituacional en apariencia, pero caleidoscópico en profundidad. En respuesta a esto, ha aparecido un libro que posibilita comprender la realidad mundial actual configurada por la pandemia de la Covid-19, y que aporta múltiples perspectivas conceptuales, orientaciones políticas y compromisos éticos para reflexionar en torno a ello. Bajo el título Sopa de Wuhan, editado por Pablo Amadeo, editorial Aislamiento Social Preventivo y Obligatorio (ASPO), el libro en sus 188 páginas discurre diecisiete escritos con quince autores de diferentes nacionalidades.

El libro presenta una estructura básica conformada por la dedicatoria en nombre del médico de Wuham quien trató de poner en alerta la aparición de una enfermedad respiratoria con rasgos al conocido SARS de 2003, señor Li Wenliang (1986-2020), sigue al índice una corta nota editorial. Las fechas de aparición de cada escrito han sido el recurso para ordenarlos en el cuerpo del libro. Una lectura detenida de los escritos permite encontrar, por lo tanto, ideas e intenciones por parte de los autores que posibilitan una agrupación por ciertas categorías. Del libro reseñaré los escritos que dan cuenta de los dos categorías que he denominado Entre el pesimismo y el realismo y Por los caminos (ambiguos) de Asia.

\section{Entre el pesimismo y el realismo}

Crónica de psicodeflación, de Franco "Bifo" Berardi, extenso diario de moderada cercanía a la crónica, registra el movimiento del coronavirus entre el 21 de febreros hasta el 13 de marzo. 
Un par de ideas en medio de la espesa percepción se dejan ver: el virus es una respuesta natural, la autodefensa de la tierra, su reacción autónoma en contra del actuar perjudicial que el hombre tiene en contra de ella. Al hombre solo le queda morir, sin ninguna otra opción, es su única salida. Enfermo el cuerpo social, la tierra en autodefensa va en contra del hombre, "no hay ninguna posibilidad de destruir el sistema (...). La única salida es la muerte, como aprendimos de Baudrillard.” (40).

$\mathrm{Su}$ pesimismo se debe a la corta mirada analítica. El día 2 de marzo registra: "pero el efecto del virus no es tanto el número de personas que debilita o el pequeñísimo número de personas que mata." (38). No advierte que 18 muertes en un día (marzo 2) ocasionadas por contagio del virus en su país, Italia, anuncia algo que termina por sumarse a un total de 52 fallecidos de más de 2000 contagiados.

Otra idea que logra ver la luz a medio alumbrar es la crítica a Europa por el desamparo egocéntrico que ha tenido con otros continentes. El autor, "Bifo", no dice más al respecto, solo la borrosa afirmación que los médicos pueden contribuir a superar la situación y no tanto así los presidentes.

El escrito presenta desordenada exposición y abundante e inexplicable acuñación de términos disfuncionales para el disfuncional escrito: virus semiótico, psicósfera, epidemia psíquica, virus lingüístico, biovirus, shock psicótico-viral, infovirus. Final- mente, "Bifo" lamenta no poder ir a la calle a abastecerse de comida, medicinas y droga.

La situación epidémica, de Alain Badiou, es más realista que pesimista y favorece las medidas adoptadas por los gobiernos, particularmente el francés, para hacer frente a la situación epidémica.

El análisis lo centra en el contexto francés, logrando dar cuenta de las connotaciones globales de la situación. Su principal flanco de análisis está en restarle novedad inflada a la forma como se está llamando al virus. Este, dice, es una mutación del SARS 1 del 2003, propagación en SARS 2 a causa de la inoperatividad de los gobiernos, principalmente el chino, para adelantar y sostener las investigaciones que tenían que dar lugar a su control: "siempre he considerado que la situación actual, marcada por una pandemia viral, no tenía nada de excepcional.” (67).

Por tanto, el SARS 2 (Covid -19) es consecuencia natural, así como la medida de confinamiento y el comportamiento paradójico, aunque necesario, por parte de los gobiernos hacia su población: medias tintas de bienestar con los sin techo, sin comida, sin trabajo y subsunción con el futuro de los privilegiados. El criterio para notar esto es la realidad misma, pues por mucho que se acuse al capitalismo de aberrante sistema egoísta y a los gobiernos como portavoces políticos de este comportamiento económico, el hecho mismo de la pandemia implica 
un trato complejo que involucra articuladamente "determinaciones naturales y determinaciones sociales." (71).

El autor ubica el origen y la propagación del virus en los mercados sucios de la provincia de Wuhan; corresponde es, por tanto, que los gobiernos locales afronten la situación, a sabiendas del carácter global de la misma y de la contradicción reinante entre el rasgo global de la economía y el nacional de "los poderes políticos". Por ello, lo que hagan los gobiernos es acorde con el requerimiento actual de preservar la vida, por un lado, por el otro garantizar el mercado de privilegios clasista.

Paradoja claramente solucionable y exigible de ser atendida en esos términos por la situación presente. "el Estado es obligado, incluso yendo más allá [d]el juego normal de su naturaleza de clase, a aplicar prácticas tanto más autoritarias como más globales para evitar una catástrofe estratégica." (74). Y concluye: "Es una consecuencia perfectamente lógica de la situación, cuyo objetivo es frenar la epidemia”. (74).

Realismo no implica oportunismo legitimador del orden presente, y esto queda claro con el autor cuando marca las nefastas consecuencias del desmonte histórico del servicio de salud de alto nivel, "y en verdad todos los sectores del Estado que estaban al servicio del interés general.” (75).

Sus mayores consecuencias in- terpretativas surgen cuando analiza las medidas del presidente francés E. Macron. Él es, afirma, solo un fiel gobernante capitalista que obra en consecuencia, asunto no entendido por la izquierda oportunista de su país. Corresponde tomar medidas que integren, no que resuelvan, los intereses de clase. De ahí que no haya motivo para alentar proyectos de revolución surgidos de la situación epidémica. Las revoluciones han sido engendradas por dos revoluciones, y ninguna ha tenido que ver con virus: la rusa de 1917 y la china de Mao. "La lección de todo esto es clara: la epidemia actual no tendrá, como tal, como epidemia, ninguna consecuencia política significativa”. (77). También es claro que ser realista tampoco implica ser acertado.

Finaliza con el optimismo de aprovechar "el interludio epidémico, e incluso, el confinamiento (por supuesto necesario), para trabajar en nuevas figuras de la política, en el proyecto de lugares políticos nuevos y en el progreso transnacional de una tercera etapa del comunismo, después de aquella de su invención, y de aquella, interesante pero finalmente vencida de su experimentación estatal.” (77). Lo demás es oportunismo populista.

A simple vista pareciera una descripción de la situación; sustenta cada idea y logra el desmarque analítico y prediccionista de otras reflexiones. Asume que tendremos que seguir obrando en pro de "la salud pública, las escuelas y la educación igualitaria, el cuidado de los ancianos y otras cuestiones del mismo género.” (78). Se sal- 
da la duda de ser el autor portavoz del estado clasista, como el escrito puede insinuarlo, pero solo insinuarlo.

\section{Por los caminos (ambiguos) de Asia}

Byung-Chul Han analiza en La emergencia viral y el mundo de mañana los dos tipos de medidas más relevantes para contrarrestar la emergencia del virus: Asia y Europa.

En dos breves apartados expone su idea matriz de resaltar los rasgos tecnológicos y de permeabilidad de la vida social por dispositivos electrónicos para reconfigurar la sociedad y sus respectivos problemas, incluidos la emergencia viral; diferente a los rasgos autoritarios dominantes en $\mathrm{Eu}-$ ropa. Cabe mencionar la perspectiva eurocentrista en el autor, solo que la emplea para apoyar su asiacentrismo.

Denuncia al continente europeo y sus gobiernos locales de tomar decisiones desesperadas y absurdas, como el cierre de fronteras, mientras Asia ha logrado controlar mejor la pandemia y, por lo tanto, "Europa está fracasando." (98).

Primer apartado, Las ventajas de Asia, se evidencian los rasgos psicológicos y políticos de los asiáticos para tener éxito en el manejo de la situación: "libertad autoritaria", "personas menos renuentes y más obedientes" que "confían más en el Estado", para quienes la "vida cotidiana está organizada mucho más estrictamente" y, "sobre todo(...), apuestan fuertemente por la vigilancia digital.” (98).
El "sobre todo" reviste importancia, por ser donde el autor hace palpable la clave asiática: volcar la ciencia $\mathrm{y}$ las investigaciones no a las personas directamente, como separarlas unas de otras, sino en el manejo informático y de macrodatos que se haga de cada ciudadano. El autor defiende su idea al introducir la experiencia de China sobre el sistema de crédito social, donde cada ciudadano es controlado al extremo y, según su comportamiento se le asignan o debitan unos puntajes que serán redimidos, en últimas, en libertades o restricciones. $\mathrm{Al}$ autor causa grata impresión que los chinos no conozcan el término "esfera privada". "En China hay 200 millones de cámaras de vigilancia”. (100).

Esto aplicado a la emergencia viral, ha representado que los chinos tomen la temperatura corporal de sus ciudadanos con alta precisión al salir de la estación de tren en Pekín. Si la temperatura excede la normalidad de uno de ellos, los demás pasajeros recibirán un mensaje en sus teléfonos móviles alertando del caso. La descripción se extiende en más detalles, de lo que destaca la omnisciencia del Estado sobre cada ciudadano. Posterior al caso China, señala lo logrado por Wuham, Taiwan y Corea.

Destacadas las ventajas de Asia, la segunda mitad del apartado es dedicado a señalar las desventajas de Europa. Una de ella es: "Mientras las personas se sigan aglomerando en los autobuses o en los metros para ir al trabajo sin mascarillas protectoras, la prohibición de salir de casa lógicamente no 
servirá de mucho.” (106). En este punto el autor no pone su innegable aguda analítica para ir más allá y señalar los factores causales que conducen a la ineficacia de la medida, fundamentalmente los referidos al funcionamiento propio del sistema económico que hace que personas tengan que arriesgar a voluntad su vida para tratar de conservarla, y por ello, no poder dejar de asistir al trabajo.

También su capacidad reflexiva de alto coeficiente delata su negligencia analítica para superar afirmaciones como que Europa ha dejado de producir "determinados productos, como mascarillas protectoras o productos medicinales y farmacéuticos.” (106). Un poco de realismo haría reconocer que sí hay producción de productos medicinales, solo que a demanda y capacidad adquisitiva.

A raíz de su visión que el mundo se ha acostumbrado a vivir "sin enemigos", concluye que es desproporcionado el pánico que se ha producido por causa de la pandemia. Lo dice a raíz de su visión que el mundo se ha acostumbrado a vivir "sin enemigos".

Segundo apartado, Umbrales inmunológicos y cierre de fronteras, se inaugura con la última afirmación. Agregando que el mundo amargamente se ha acostumbrado a vivir en la "sociedad de la positividad". Afirmación fuerte para no ser sustentada con suficiencia; de algo se perdió el autor para no recordar otras epidemias, atentados terroristas, crisis económicas, desahucios, guerras civiles, gol- pes militares... el viaje de Corea del Sur a Alemania al parecer suele tomar su tiempo.

Dedica las líneas finales para ir en contra del optimismo de Zizek. "Ningún virus es capaz de hacer la revolución” (110), por consiguiente, "Zizek se equivoca", "nada de eso sucederá." Queda por conocer la fuente de certeza a la que acudía el autor como para saber que Zizek se equivocaba y que él tenía la revelación para decir que "el capitalismo continuará aún con más pujanza." (110). Ambos profetizan sobre espuma.

Inclinación pronunciada de la balanza a favor de Asia. China ahora produce una mercancía llamada "Estado policial digital" necesaria de ser importada por Europa.

Pareciera que el problema del autor no es propiamente el autoritarismo de Europa, sino la falta de creatividad y reinvención de este; los asiáticos tienen éxito y llevan ventaja en tanto su autoritarismo es tecnológico, sus dispositivos de control son menos visibles y más eficaces. La era digital salva al mundo, más que virólogos y epidemiólogos. Camino ambiguo el que recorre el autor, y no solo por salir de Asia e ir a Europa para hablarle a los asiáticos de los europeos, sino por la segunda mitad del último párrafo del escrito: ¿en últimas más cercano a Zizek que de Alemania? Con su estilo pausado y categórico destaca ideas cuya novedad suele chocar con la virtualidad y artificialidad del trato del "tema". 
Raúl Zibechi escribe A las puertas de un nuevo orden mundial. Se propone comparar las medidas adoptadas por Asia frente a las de Europa, Estados Unidos y Latinoamérica, siendo favorables las asiáticas para combatir la pandemia.

Hace una referencia histórica para forzar el sustento al optimismo presente: "La pandemia supone la profundización de la decadencia y crisis del sistema que, en el corto tiempo, había comenzado en el 2008, y en el largo se extiende desde la revolución mundial de 1968." (113). ¿Nostalgia juvenil-estudiantil de un hecho que nunca tomó el vuelo de revolución?.

Pasa a presentar las medidas de Asia como "referente y ejemplo". El ascenso económico chino lo llevará inexorablemente a ser hegemónico, así lo indican sus raíces históricas: desde la guerra del opio hasta la invasión japonesa. Por su parte, Estados Unidos va en dirección opuesta: "gobierno errático, imperial y machista" (114); la Unión Europea peor aún: "desde la crisis de 2008 perdió su brújula estratégica” (114); Latinoamérica junto a los norteamericanos y europeos "sufrirán los efectos económicos de la pandemia con mucha mayor intensidad que los asiáticos.” (115).

En un único apartado titulado Hegemonía tecnológica muestra el poderío tecnológico chino (farmoquímico, automotriz, aeronáutico, electrónico $\mathrm{y}$ en telecomunicaciones), superior al de Estados Unidos. Sin embargo, critica el control social asfixiante del gobierno a su población. Ambigüedad asiática que se resuelve al comprender que el desarrollo tecnológico en una sociedad autoritaria tenga como consecuencia natural el uso de esta para el control exhaustivo de su población.

Algo de predicción, mucho de arenga juvenil en asamblea popular la que trata de sostener a un escrito sin columna vertebral.

La diversidad interpretativa del libro ofrece al lector una perspectiva amplia, aunque la misma se torne con regularidad conflictiva e incluso excluyente, pero, justo esa es su riqueza discursiva. Como obra antológica, el lector logra pensarse a sí mismo en tiempos donde el "volver dentro de sí", obligado para el caso, posibilita mirar el mundo con mayor detenimiento, aunque con menor calma.

\section{Referencias}

Amadeo, P. (Ed.). (2020). Sopa de Wuhan. Argentina: Editorial Aislamiento Social Preventivo y Obligatorio (ASPO). 